\title{
Paraguaçu Waters: Microbasin Ecologic restaurantion from Córrego Ibicoara, Mucugê, Chapada Diamantina, Bahia, Brasil.
}

\author{
Ana Cláudia Costa Destefani ${ }^{1^{*}}$, Denilson Barbosa de Oliveira ${ }^{2 *}$ e Rejane Carneiro Salvador de \\ Oliveira ${ }^{3 * * *}$
}

\author{
${ }^{1}$ Instituto de Permacultura da Bahia (IPB), Salvador, Bahia, Brasil \\ 2Instituto Brasileiro do Meio Ambiente e dos Recursos Naturais Renováveis (IBAMA), Salvador, Bahia, \\ Brasil \\ 3Instituto Pedagógico de Desenvolvimento Agro-social e Comunitário (INPAC), Itaetê, Bahia, Brasil \\ E-mail for contact: *biodestefani@gmail.com**denilson.oliveira@ibama.gov.br \\ *** rejanecarneiro2000@yahoo.com.br
}

\begin{abstract}
The Ibicoara Stream Microbasin, localized between Ibicoara and Mucugê cities, Chapada Diamantina, Bahia, Brasil, belongs to the Alto Paraguaçu Hidrographyc Basin, which is the object of study from Águas do Paraguaçu Project. The aim of the Project is to reverse the environmental degradation process in priority areas of Atlantic Forest's Biome, through ecologic restoration actions in 30 hectares with Fazenda Ibicoara Community. It is an iniciative of the Public Prosecution Service of the State of Bahia, with the financial support of the José Silveira Foundation, execution by Instituto de Permacultura da Bahia - IPB, in partnership with Brigada Federal de Assentamento Diamantina, from Centro Nacional de Prevenção e Combate aos Incêndios Florestais PREVFOGO/IBAMA, that offers support with speeches, arceiro negro reparation and confection, and a partnership also with Instituto Chico Mendes de Conservação da Biodiversidade - ICMBio in actions related to arceiro negro implantation and preventive hunting supervision. The 42 rural properties, from 35 families involved in the Project, composes the Fazenda Ibicoara Comunity. These areas, mainly the nearest to southwest portion of the Chapada Diamantina National Park, suffered deforestation, forest fires in Atlantic Forest remnants and an alternative land use. The ecologic restoration process began in 2016, with the Fazenda Ibicoara Community involvement, from awareness raising to the other stages as: Elaboration of 42 participative restoration plans from degraded areas; withdrawal of the degradation factors; actions to improve the landscape permeability, as living fence planting, afforestation of coffee plantation and Sistema Agroflorestal (SAF) implantation; regional native species plantations with distinct techniques, in forest fragmented and deforested areas; ecologic restoration maintenance and monitoring, and, capacitation throughout lectures, courses and field classes. Were implemented 21 restoration techniques for degraded areas, using 110 regional species and 40.000 plant seedlings with a $5 \%$ mortality rate in October 2018. Since 2016, there has been local community integration, result attributed to the Project, which has been connecting forest, people and business.
\end{abstract}

Keywords: Microbasin, environmental degradation and ecologic restoration. 